\title{
THE RELATION OF GOVERNMENT TO FOREIGN INVESTMENT
}

\author{
By Huntington Wilson, \\ Formerly Assistant Secretary of State.
}

The relation of government to foreign investment by its citizens is one of correlative obligation and authority, general obligation to protect the citizens' rights, and authority to control the citizens' course by giving great or little protection, or none at all. In the discharge of its obligation the duty of government is to measure the protection to be given any investment first of all by the advantage of that investment to the nation; and secondarily to mete out that protection in proportion to the right of the investor to expect protection.

The authority correlated with the obligation to protect is that involved in the power to vary, in accordance with the criteria above cited, the degree of protection, if any, to be afforded in the case of a given investment. Without any legislation on the subject, the government's authority is automatically of determinative potentiality in this question of foreign investment in all countries except those of the highest credit and stability. And even in the case of such countries, an adverse intimation from Washington would tend to have a blighting moral effect upon a proposed investment of American capital.

From the days of the struggles of Phoenicians, Carthaginians, Greeks and Romans in the Mediterranean down to today, it has been power, and above all sea power, which alone has protected foreign trade. Even in these allegedly softer times, we must admit, now at least, that it is only under the shadow of the great powers, those prepared or potentially able to use great power, that small countries like Belgium, or even relatively weak, although great, countries can, as independent nations, carry on a big foreign trade. The governmental relation to foreign investment in its authority and obligations presupposes and demands power. 


\section{The Relation of the Government to Formign Enterprise}

For the purposes of this discussion, we shall do well to consider the relation of government to foreign trade and to all sorts of foreign enterprises, as well as to investment in the narrower sense of shares and bonds, because the same principles apply to all alike. It may at first sight seem an extreme view, but one may go farther and apply similar general principles even to the relation of government to the presence of its citizens to reside for any purpose in any part of the world.

The relation we are considering is one to be dealt with by the diplomatic department. Like other questions of real and statesmanlike diplomacy, this question derives its importance and its charm and interest from its farspread ramifications and concatenations. It carries into the far future and it brings many sciences out of the "conference stage" to an entirely practical application in every day international business. Here, as elsewhere, diplomacy becomes everything that concerns one's country, fostered through its foreign relations.

During the four years preceding the present administration, when Mr. Knox, as Secretary of State, gave a new definiteness, intelligibility and practicalness to American diplomacy, the policy toward foreign investment was epitomized thus: "The Department (of State) will give all proper support to legitimate and beneficial American enterprises in foreign countries." This formula was the invariable answer to the prudent investor desiring to know in advance what would be done for him if, through no fault of his own, he got into trouble, due, say, to oppression or failure to protect on the part of some foreign government.

Now the government's obligation to protect a particular American interest abroad must, in its discharge, be measured and meted out, as has been said, in proportion to the benefit of that particular interest to the nation as a whole. Whatever influence or force the government may exert in the world is the prestige and power of the nation. Consider this collective power, moral or physical, as a great reservoir. The executive branch of our government has constitutional authority to conduct foreign relations untramelled except by the authority of the Senate when it comes to a treaty, by the authority of the whole Congress when it comes to an appropriation of money, and in some few other respects. This authority is so 
appallingly broad, one may remark, that it becomes of vital necessity that the United States should have fundamentals of foreign policy that are accepted by the whole nation, to be permanent bases of action in all specific questions of importance. Otherwise the American people can be involved by the executive without referendum in any folly during every four years between presidential elections. Even party platforms about foreseen questions are no safeguard, for we see them violated, as in the Panama Canal tolls question with Great Britain. Now this startling breadth of executive authority in diplomacy places the executive, as trustee of the nation's international influence, under obligations of the greatest solemnity and weight. Therefore how much thought must the Secretary of State take before turning the tap of the reservoir and drawing off for the protection of a foreign enterprise a measure of the national prestige and power entrusted by the people to his care!

\section{“Dollar Diplomacy"}

This theme and its illustration by example lead to an exposition of what has been called "Dollar Diplomacy." It might better be described as common sense diplomacy, in contradistinction from the diplomacy of perfunctoriness or that of whimsical sentimentality from which the United States has suffered so much. It is submitted, moreover, that one who will carefully study the so-called "Dollar Diplomacy" will be fully convinced that it was a diplomacy of common sense in the highest sense of that term, that is, a diplomacy determined by the application of scientific principles and sound thinking to plain facts studied and understood as they really are; a diplomacy preferring to build for the long future, rather than to dogmatize for the moment's expediency; preferring the truth to a beautiful idealization not resting upon truth.

Now the national advantage of a foreign investment may consist in (1) political advantage or (2) economic advantage. Service to humanity is not mentioned separately because charity begins at home; because it is America's first duty to serve America; because America, as a government, can amply serve humanity in spheres and in ways in which America also serves itself; and because if it does that, the service to humanity may be considered by diplomacy, which is not, by the way, an eleemosynary institution, as merged in the service of America, that is, in American political advantage, 
Those who dissent from this view and yield to our national foible for grandiloquent sentimentality ought to reflect that a trustee, however admirable his private charities, would be put in jail if he used trust funds for benefactions; and that exactly so the American executive defrauds the nation if he uses its prestige and power in a diplomacy directed by sentimentality to the service of humanity in general, instead of a diplomacy seeking the political and economic advantage of the American taxpayer, the American nation.

\section{Political Advantages of Foreign Investment}

Political advantage (1), then, comprises such factors as (a) strengthening American infuence in spheres where it ought to predominate over any other foreign influence on account of reasons of fundamental policy, like the Monroe Doctrine, or of military strategy or of neighborhood. Such a sphere is "Latin America," where our interest increases in intensity from a vanishing minimum at Cape Horn northward to reach its maximum in the zone of the Caribbean Sea, the neighborhood of the Panama Canal, and in Mexico. In this category falls also, for example, the discharge of our historic obligation to Liberia and the preservation of that little country as a pied-a-terre in Africa, of possible potential value to us for commerce or for the emigration of African Americans. Such political advantage ranks highest. Next comes (b) the maintenance of a traditional position favorable to our trade where trade may go by political favor, as in the Chinese Empire. Other cases of political advantage would be (c) the strengthening of our friendship with other great powers, or (d) with countries where it is wise to preëmpt a share in a dawning development, like Turkey, or (e) with countries whose markets are especially valuable. The cases merge so gradually into one another as to make clear cut classification difficult. This is true also of the division of political from economic advantage. The idea is that in some cases trade is important primarily for its political effects through mutual interest and association, while in others a good political relation is valued (if not for safety and advantage in actual coöperation or alliance) for its tendency to favor trade. The student of American diplomacy will readily enough place our relations with different countries in appropriate categories even without an attempt at nicer classification than is here intimated. 


\section{The Economic Advantages}

Inasmuch as political advantage comprises whatever touches national security, the first place in importance, among economic advantages, must be given to (a) those investments or enterprises which most promote vital political interest. Next most important in economic advantage to the nation and usually identical with (a) are (b) foreign investments or enterprises which establish permanent and valuable markets for trade while at the same time subserving political strength where the policy of this country demands that it be strong if we are to have security and tranquility. Other cases are (c) investments or enterprises which have these same purely material advantages while carrying with them some political advantage as well, as, for example, in safeguarding our Chinese trade; or (d) those investments or enterprises which serve in giving us a commercial standing in some valuable market where development may be preëmpted by others if a footing be not early obtained (like Turkey); or (e) in cementing friendship with our natural allies, as Canada and the English speaking peoples generally; or (f) in bringing profit and employment to the American people in general.

In the encouragement of foreign enterprise, diplomacy must beware of forcing it into spheres where vexations conflict with the special spheres of influence and interest of other countries outweighs all commercial gain to be looked for. Every great power has some "doctrines" that it conceives to be as vital to it as the Monroe Doctrine is considered here. Korea and Manchuria, Persia and Siam, come to mind as examples of territory where, while conducting ordinary trade, we should be wasting our energies to attempt intensive developments. In return we should gradually crowd out from our own sphere of special interest foreign interests wherever they are predominant to an uncomfortable extent and quite beyond the requirements of an ordinary trade outside the spheres of special interest of the foreign governments concerned.

Quite aside from this common sense circumscribing of our spheres of greatest effort to make them comport with the facts of world politics, it is still true that there is not enough American capital yet available for foreign investment thoroughly to cover the duty of consolidating our economic position in the spheres where that necessity is most obvious. Also, there is a lack of men trained for this work and willing to reside under tropical rain, amidst moun- 
tain peaks, on broad savannas, and in ancient cities of manners and ideas quite alien to our own, in order to carry it on. "God gives a man his relatives; he chooses his friends." A nation is less fortunate. The hazards of history have made us a sphere of vital interest which we have to cultivate, however difficult it be.

\section{Proper Support to Legitimate Enterprises}

Let us return to the formula. "The Department (of State) will give all proper support to legitimate and beneficial American enterprises in foreign countries." A legitimate enterprise must be honest and fair, and just to the foreigners concerned. But it may be legitimate so far as the interested American is concerned and beneficial to him individually while not beneficial to the nation. Such would be the case if the dangers of seriously involving this country in fresh obligations outweighed any national advantage; if the investment diverted from channels of real national advantage money that might otherwise serve that advantage either abroad or at home; or if the project involved offending a valued friend among the nations. To merit the strongest governmental support, the foreign investment or enterprise must be really beneficial to the nation.

In the formula, the phrase "all proper support" is advisedly indefinite. The Secretary of State must reserve the question of how much support will be "proper" in a given case, because when the question is asked it is a hypothetical one; because the question will be a political question, to be affected, perhaps, by changing conditions; and because, above all, it will be one involving the careful consideration of subtle measures of national advantage,-which is the first measure, as the citizens' right is the second measure, of the government's support. The government's obligation is its duty to the citizen, but the coefficient of that duty is its duty to the nation.

Proper support is the discharge of the government's obligation, limited by its variant authority or power, expressed in terms of action, diplomatic, or in the last resort, warlike. And that proper support is the duty to the citizen plus or minus the sum of political and economic national advantage.

This almost mathematical expression of the theory of "Dollar Diplomacy," to use the approbrious nickname, may assist a clear 
understanding of a subject deplorably little considered by our countrymen. Illustration, however, will perhaps supply vividness to a dry statement.

\section{Applying "Dollar Diplomacy"}

Without law, it is of course only where the citizen thinks he may ultimately need his government's help to "pull his chestnuts out of the fire" that he can really be controlled. He will buy AngloFrench bonds in full faith in the honor and stability of Great Britain and France. If he jumped into a pet private preserve of Great Britain or France and engaged in enterprises subversive of some policy of "protection, guidance and control" (to quote the classic of Japanese aggression in Korea), it is not intended to imply that his government would abandon him to his fate. It would seek equitable damages for him, but probably not specific performance. So it was, in principle, to give an analogous example, when the American advisers were forced out of Persia by Russia and England. American influence in Persia was of no account to our national interest. An equitable adjustment doing justice in a general way to our citizens, would in such a case be proper policy. If, on the other hand, those advisers had been in a country where American influence was of national importance, the American government must have resisted their dismissal and insisted upon specific performance, although the contracts were no more binding in the one case than in the other.

The convention with Santo Domingo, the agreement with Cuba involving certain public works, the convention of 1911 with Honduras (rendered abortive by the vote of an adverse party majority in the Senate), the old arrangement and convention with Nicaragua, carried out after a fashion by the present administration, the loan policy with China, which the present administration promptly killed and now has made an unsuccessful effort to resuscitate,--all these involved foreign investments of such great and unquestionable national advantage that the government was an active participant in them; and, by urging on the investors to lend themselves as instrumentalities of foreign policy, the government clothed those investors with rights to protection of especial dignity.

Since this is not a discussion of American diplomacy at large, but is confined, so far as practicable, to one phase of that subject, 
those transactions need not be described at length. Suffice it to say that the object of the Central American policy was "to substitute dollars for bullets," to create a material prosperity which should wean the Central Americans from their usual preoccupation of revolution. Those countries have great natural wealth. Lack of capital, lack of skill, and still more the absence of any guarantee against confiscation and destruction due to the frequent revolutions when law and order are thrown overboard, prevent the development of their natural wealth by the people themselves. The same conditions throttle their export trade and destroy their purchasing power. Attacks upon American interests, and even upon the personal safety of American planters and others engaged in those countries, call for our government's protection. The similar jeopardy of European interests demands, as an unavoidable corollary of the Monroe Doctrine, the protection of the American government. For the frequent interventions, moral or physical, thus necessitated, we had no convenient base. With great pertinacity certain far away European powers, with an effrontery engendered by the inchoate state of American foreign policy, have been at great pains to poach upon our preserves in the Caribbean and even on the Isthmus itself. In Central America, as in Columbia in theory, there was the question of an alternative inter-oceanic canal route, and that was a basis inconveniently open for the preëmption of a special interest which we could not afford to see go to others than ourselves. Trade with Central America was retarded by the lack of railways and by financial instability. The ports of our southern states, the logical centers of this rich trade, were being deprived by those adverse conditions of a profit due them from the facts of geography. It is true that one or two of the republics of Central America are in far better condition than the others. To cite a case where the political and economic advantages are both of the first rank and where, therefore, the measure of governmental support should be at its highest, I will refer to the policy toward Nicaragua, which illustrates only more completely what should be the spirit of our policy throughout the zone of the Caribbean. Indeed as now implemented our policy in effect is the same in principle in Panama, Cuba, Santo Domingo and Haiti. 


\section{Odr Policy Toward Nicaragua}

In Nicaragua a New York bank of the highest standing was induced to invest in the financial rehabilitation of the country, its transactions giving it an interest in the railways and in the customs revenues, which it is always desirable to remove from the reach of revolutionary depredations. Americans were engaged as financial advisers, as claims commissioners and in other important capacities. A convention was signed to give the United States a naval station in the Gulf of Fonseca, dominating three of the republics. A perpetual option upon the Nicaraguan canal route was assured us. A large sum of money was to be advanced Nicaragua for its most pressing needs, but to be expended only under American supervision. The full fruition of this plan was postponed by partisan opposition in the Senate, but it was later taken over, in a general way, by the present administration and may now, it is hoped, meet a kinder fate. An outstanding feature of this particular policy is its effort to help our neighbors to help themselves and to do so in practical ways, which advance at the same time the very real and quite legitimate and indeed the inevitable interests of our own country.

The Nicaraguan arrangements are so comprehensive that they serve to illustrate many phases of the same policy we have seen pursued in Cuba, in Panama, in Haiti, in Honduras. The public revenues, especially the customs dues, must be placed out of reach of the revolutionary robber or the dictator. Capital must be brought in to establish peaceful husbandry and unmolested industry. Education and civilization must bring justice. A guiding hand must prevent foreign entanglements, which, under the Monroe Doctrine, straightway involve us. Even if the Monroe Doctrine had never been announced, common prudence would today force upon us the same policy from our southern border throughout the zone of the Caribbean.

\section{The Law of National Survival}

No far seeing policy, but a natural human movement, accounts for the vast American investment in Mexico and for the penetration of thousands and thousands of Americans into Mexican territory as planters and miners and workers. Here a natural law and a political theory work together, as is the case whenever the political theory is sound. There are so many analogies between biology and inter- 
national evolution that one may invoke a sort of "international biology." The march of civilization brooks no violation of the law of the survival of the fittest. Neighboring countries comprise an environment. The strongest will dominate that environment. Sentimental phrases about the sovereignty of weaker countries will no more permit them to run amuck with impunity than ranting about individual rights will permit an outrageous citizen to annoy a municipality and escape the police. The biological law of the tendency to revert to the lower type as the higher attributes are disused is at work among nations; and nature, in its rough method of uplift, gives sick nations strong neighbors and takes its inexorable course with private enterprise and diplomacy as its instruments. And this course is the best in the long run, for all concerned and for the world. The murder of two or three German missionaries in far-off China, cost China Kaichow and practically a province. The murder of many Americans in nearby Mexico, where by every law of neighborhood and policy they had a special right to be and to be protected, has cost Mexico so far - the reading of a great many communications. Life is priceless; but what of the investors, great and small? Here is a case where political and economic advantage to the nation are at a high level, where the government's obligation to protect connotes a great degree of support as proper. This is so because no field of investment is more natural than that over the border, which fact gives the citizen the right to expect support, subject to the national interest concerned, in this case a high coefficient. If so much be granted, the support, it has been said, is limited by its (the government's) variant authority or power. Since no one doubts its power, our government's task then becomes one of ways and means, with the evident duty of sparing so far as possible our own blood and treasure. The seizing and holding of revenues amply to cover all actual damages at once suggests itself as a practical measure and one readily assimilable with the chastisement and chastening due from us if we do not repudiate the duties imposed upon us in the nature of things by laws as real as those of biology.

This digression is perhaps excusable as anticipating the question of ways and means of protecting foreign investments and enterprises in various cases which differ as widely as the one just described differs from an economic question with a first-rate power. There, 
too, we bungle and are unprepared. We lack the weapon of a sliding-scale tariff, with discretion in the Executive to force justice to our interests by the threat of effective and prompt retaliation.

\section{The Six-Power Loan Policy in China}

The six-power loan policy in China is in point upon this question of how the government would protect its citizens' investments. Aside from the high repute of the Chinese people for commercial morality, what with the turbulent conditions of the Empire and its distance from us (except in the Philippines) one might say that the American government could ill afford to undertake to protect its citizens in great investments there. In China we have a traditional position of friendly concern and a commerce that once promised very well. But we have not the political mandate of a cardinal principle of policy nor the natural mandate of neighborhood as we have in Mexico.

Mr. Knox "pooled" our interests in vast railway constructions and currency reform, involving huge investments of capital, with the interests of five other great powers. In this way, America secured its share in those lucrative undertakings while its share of responsibility in protection was only one-sixth of what it otherwise would have been.

Let us further examine that Chinese policy which the present administration in a heat of partisanship so ruthlessly reversed, to learn later, as it did in respect to a number of other matters, that foreign policy is not domestic politics. We may be our "brother's keeper" in the case of Mexico. We are certainly not China's keeper. I do not therefore attach to the purely political aspects of our Chinese policy quite the same importance that some do. There is working in the Far East an "international biology" that we have neither duty nor interest in radically interfering with. Times have changed since Mr. Hay expressed in idealizations about the "integrity" of China the good will America had always felt for that Empire. However, we wanted and we still want the "open door" of ordinary equality of commercial opportunity. Before showing how Mr. Knox's policy served those practical ends, the political aspect may be touched on, although it is rather one of sentiment than one related to a policy of the first class that a nation would fight alone for. 
Naturally enough, Russia and Japan have designs upon outIying Chinese territory and certain Chinese provinces. Manifestly, to concatenate great interests of theirs with great interests of four other powers preferring to preserve China pretty well intact would tend to create a community of interest in the preservation of China's integrity. If two men with certain intentions were chained to four men with other intentions, the course of the group would differ from the untramelled progress of the first two men. Thus, without any offensive or radical interference with other nations' natural expansion, the United States, with Great Britain, France and Germany would have had a share in the first practical arrangement ever suggested to work with any effect along the lines of the rather illusory declarations of Mr. Hay.

\section{Significance of the Knox Policy toward China}

Turning from this now more or less chimerical consideration, we note the really brilliant statesmanship of Mr. Knox in placing us, with no danger and with only a small share of responsibility, and that divided with powerful partners, in a position not only of dignified equality, but of actual leadership in the large concerns of the Chinese Empire! To realize how important that rôle was to our general Chinese trade one must know China. Besides indirect effects, the Chinese arrangement gave us such economic national advantages as these: American engineers would be appointed and American railway materials would be used on our proportional part of the whole railway system. That meant money to American industry. As to the bankers' profits in the loans and the ultimate bondholders' income, they were good for the country too, economically, but were so clearly a means to a greater end that the bankers had to be urged into the whole transaction and, during its difficult course, often urged to remain interested. If this had not been done, and if American bankers had not responded with a good deal of patriotism, the biggest transactions ever undertaken in China would have proceeded without the least participation by the country which had officially talked most of China's opportunities.

Reference to the direct economic advantages to the nation to be found in the railway loans to China brings us to a few last comments upon the measures of economic advantage in foreign investments. Lately a gentleman prominent among those who are at 
last making a campaign for foreign trade spoke of Russia as a great field for American enterprise and in doing so spoke particularly of the opportunities for branch factories. Now this question of "extraterritorial enterprise" is a familiar one to the practical diplomatist. A branch factory in a foreign country may be very profitable to the capitalist, and it will be better than nothing in so far as it brings money into the United States; but it does not directly pay American wages or enrich and build up American communities, as do great foreign orders to be executed in American factories at home. Therefore the foreign branch factory is of relatively slight national advantage and has relatively small claim on the benevolent interest of the government. Such, by the way, would not be the case of an American factory established where it was especially desired to strengthen the national influence, particularly if the factory was not in point-blank competition with a home factory and in that way deflecting wages from Americans to cheaper foreign labor on the spot.

\section{The Government Should Guide Foreign Investments}

The necessity of having our exports paid for ultimately in goods or securities (and not always in gold) makes it of interest to the government to encourage investment in certain countries. We cannot, for example, buy the coffee crop of all Latin America. Indeed to encourage here, to deter there, in short, more or less to guide foreign investment, is a proper function of government. There should not be obligation without authority. The value of our home investments rests, in the last resort, upon our municipal law. The value of our foreign investments rests, in the last resort, upon our diplomacy, the conduct of our foreign policy. The efficacy of these depends upon our prestige and our military power, and these last are the possession of the nation.

There would thus be a logic in a requirement of official permission to list foreign securities in our markets or to undertake certain foreign enterprises. For the exercise of this discretion we should need a little law. It might be vested in a small committee, for example, of competent officials of the Department of State, of the Treasury and Federal Reserve Board, with the Chairmen of the Foreign Relations and Foreign Affairs committees of Congress.

It seems, after the question has been mooted for years, that 
we still need a law (perhaps!) to keep the Sherman Anti-Trust law from frightening our manufacturers and merchants out of their right to combine to compete with Europe in foreign commerce. Only now have our laws a little helped our bankers to establish themselves abroad and to give our trade and enterprise the needed facilities. We are very backward in foreign affairs, commercial, financial, and political, and disposed to neglect all that hard ground that lies between great visions and small details. The end of the war will leave with the problems of foreign investment and enterprise and the government's relation thereto a new urgency. And laws or no laws, if we are to deal wisely with them, the realities of American diplomacy must become matters of conscious concern and intelligent interest to American citizens. Only so can government be compelled, under our system, to perform its task of leadership, to make effective its proper relation to foreign investment and enterprise. 